\title{
Travesías, un viaje entre libros y lecturas en la Biblioteca de la Academia Argentina de Letras
}

Beatriz C. Valinoti

Universidad de Buenos Aires. Facultad de Filosofía y Letras. Instituto de Investigaciones Bibliotecológicas, Argentina | bvalinoti@filo.uba.ar / http://orcid.org/oooo-0oo3-2569-4187

\begin{abstract}
Resumen
En los últimos años, el estudio de la historia cultural ha experimentado un extraordinario desarrollo y, dentro de ese marco, se ha profundizado el conocimiento de la sociedad a través de lo escrito, lo editado y lo leído. De modo que partiendo de considerar que los libros adquieren nueva vida cuando son recuperados en su significación textual, en sus condiciones de producción y sus materialidades, se analizarán algunas ediciones argentinas del siglo XIX presentes en el catálogo de la Biblioteca de la Academia Argentina de Letras. Se entiende que este enfoque permite estudiar los textos en múltiples dimensiones. Así, y tras pasar del mundo del impreso al mundo del lector se intentará encontrar respuestas a viejas preguntas -como las que se encuentran en el Almanaque Indicador Argentino (1899)- desde nuevas perspectivas de comprensión de la multiplicidad y diferenciación de las prácticas culturales, mostrando al autor y sus textos, al editor y sus ediciones para llegar a los lectores y a las estrategias desplegadas y sentidos compartidos alrededor de los libros y las lecturas en Argentina.
\end{abstract}

\section{Voyages, a journey through books and readings in the Academia Argentina de Letras}

\footnotetext{
Abstract

In recent years, the study of cultural history has undergone an extraordinary development and, within that framework, the knowledge of society has been deepened through writing, publishing and reading. So, starting from considering that books acquire new life when they are recovered in their textual meaning, in their production conditions and their materialities, the Argentine editions of the 19th century present in the catalog of the Biblioteca de la Academia Argentina de Letras will be analyzed. It

Palabras clave

Bibliotecas Edición Lectura Libros Argentina

Keywords

Libraries Edition Reading

Books Argentina 
is understood that this approach allows studying texts in multiple dimensions. Thus, after passing from the world of print to the world of the reader, we will try to find answers to old questions -such as those found in the Almanaque Indicador Argentino (1899)- from new perspectives of understanding the multiplicity and differentiation of cultural practices, showing the author and his texts, the editor and the editions to reach the readers and the strategies deployed and shared senses around the books and readings in Argentina.

Artículo recibido: 29-04-2019. Aceptado: 22-05-2019

\section{Introducción}

Que otros se jacten de los libros que les ha sido dado escribir; yo me jacto de aquellos que me fue dado leer.

Jorge Luis Borges (1988)

1. Esto permite reunir aportes desde la Bibliotecología, la Literatura, la Educación, la Lingüística, los Conservacionistas y Restauradores junto a otras disciplinas, que no incluyen sólo a las sociales, como la Ciencia Política y las

Ciencias de la Comunicación, sino a esas que, como por ejemplo la Física y la Química, parten de otras bases epistemológicas.
En los últimos años, el estudio de la historia cultural ha experimentado un extraordinario desarrollo y, dentro de ese marco, se ha profundizado el conocimiento de la sociedad a través de lo que se ha escrito, se ha editado y lo que se ha leído. Entre otras riquezas, esta nueva manera de enfocar estos estudios permite acercarse a disciplinas que posibilitan recorrer nuevos y diversos caminos hasta ahora no explorados ${ }^{1}$. De modo que partiendo de considerar que los libros adquieren nueva vida cuando son recuperados en su significación textual, en sus condiciones de producción y sus materialidades, es decir prestando atención al encuentro entre el mundo del impreso, el mundo del editor y el mundo del lector, se analizarán algunas de las ediciones argentinas del siglo XIX presentes en el catálogo de la Biblioteca de la Academia Argentina de Letras (AAL).

Se entiende que este enfoque permite estudiar los textos en múltiples dimensiones, desde los procesos de apropiación, lo que implica pensar en los usos y las creaciones de sentido, hasta las prácticas que otorgan condiciones de legibilidad y las que aportan elementos para la reconstrucción de los lazos sociales que materializan nuevas formas de pensar y actuar en el mundo.

Así, y tras pasar del mundo del impreso al mundo del lector se intentara encontrar respuestas a viejas preguntas -como las que se encuentran en el Almanaque Indicador Argentino (1899): ¿cómo se lee? ¿Por qué se lee y qué se busca en la lectura? ¿Todos comprenden la misma lectura de un mismo modo? Por lo tanto, el objetivo de este trabajo es pensar en nuevas perspectivas de comprensión de la multiplicidad y diferenciación de las prácticas culturales alrededor del libro, mostrando al autor y sus textos, al editor y sus ediciones para llegar a los lectores y a las estrategias desplegadas y los sentidos compartidos alrededor de los libros y las lecturas en Argentina, durante el siglo XIX. 
Si bien fueron las propuestas de Roger Chartier (1993; 1996a; 1996b; 1999; 2000a; 200ob; 2008; 2016) y Robert Darnton (1982; 1987; 1988; 1990; 1993; 2006; 2014) las que abrieron nuevas perspectivas de análisis al estudio de la cultura impresa al tomar en consideración tanto los procesos de producción, circulación, difusión, recepción como los de consumo del libro, en las últimas décadas, en Argentina, investigaciones provenientes de la bibliotecología, la crítica literaria, la historia cultural e intelectual, la sociología y la antropología fueron dando forma a una serie de estudios en torno a la producción de libros (sin por ello excluir a la prensa y otras publicaciones periódicas), los circuitos de comercialización y los modos en que han sido apropiados y resignificados en sus diferentes recepciones esos diferentes materiales impresos (Saferstein; 2013:158 y 159)².

En conjunto todas estos aportes señalan algunas de las formas en que es posible abordarse estas cuestiones, profundizar las historias de la edición en el país, discutir los problemas teóricos desde diversas tradiciones disciplinares pensando la actividad editorial como una herramienta política, cultural y económica y construir una historia de la lectura.

\section{Los lectores}

Esta es una travesía que comienza en las páginas del Almanaque Indicador Argentino, publicado y editado por Juan Schürer-Stolle en el año 1899 . Allí, en un pequeño texto, Los lectores, afirma que estos:

Son naturalmente los que leen. - ¿Pero cómo leen? ¿De qué modo? ¿Por qué leen y qué buscan en la lectura? ¿Todos comprenden la misma lectura de un mismo modo? ¿Comprenden mucho, poco ó nada? - Nosotros nos entregamos á ellos... y nos leen; ¿pero de qué modo? (Almanaque Indicador Argentino, 1899: 375). ${ }^{3}$

Resuenan desde esas páginas algunas de las cuestiones a las que se quiere dar respuesta aquí aunque la categorización de los lectores, que según este almanaque son indiferentes, distraídos, ignorantes, malignos, pedantes o prejuiciosos (Almanaque Indicador Argentino, 1899: 375), no parece ser muy propicia para encontrarlas y menos para construir una historia de la lectura. Pero, ¿por qué esta pequeña enciclopedia popular, como se define ${ }^{4}$, presenta a los lectores con estas características tan negativas? Esto no deja de ser sugerente ya que entiende que son ellos los llamados a juzgar la obra realizando las indicaciones convenientes a fin de que las ediciones sucesivas permitan que la publicación llene cumplidamente su programa (Almanaque Indicador Argentino, 1899: 3).

Luego de unas publicidades y el índice, una imagen parece dar cuenta de otra de las formas en la que se ve a los lectores. Una mujer con un pequeño librito, que puede suponerse condensa noticias de historia, ciencia, artes, literatura y otros temas presentes en los libros sobre los que se apoya, sostiene a un niño que quiere alcanzarlo, pero es ella, desde una posición de administradora del conocimiento, quien le permite ver algo. Los lectores ¿son como ese niño?, ¿quiénes pueden brindar conocimiento?, ¿cómo se puede llegar a los libros?, y además ¿se comprende adecuadamente lo que se lee? Si bien la imagen hace referencia al Almanaque Moderno Sudamericano, algunos elementos permiten vincularlo con la descripción que presenta el Almanaque Indicador Argentinos, parece haber una diferencia entre el lector pensado (por autores y editores) y el lector real (Imagen 1 ).

Si bien, para esta época, la novedad eran las revistas ilustradas, en las últimas décadas del siglo XIX los almanaques habían recuperado el auge de sus inicios, al utilizar la
2. Así se podría partir de un corpus inicial que, sin pretensión de exhaustividad y atendiendo a dichas corrientes de análisis, deberían considerar el proyecto para reconstruir la historia de la civilización impresa que ha encarado Alejandro E. Parada, especialmente desde el punto de vista de la historia de la lectura y su articulación con la Bibliotecología y la historia de la edición (Parada 2000, 2003, 2006b, 2007, 2012, 2013) la reconstrucción y el devenir del mundo editorial y la figura del editor en nuestro país (De Diego, 2007, 2009, 2015, 2019; De Sagastizábal, 1995, 2002; Sorá, 2011) o los estudios de las redes trasnacionales que tejieron los autores, los editores y otros profesionales del libro (De Diego, 2015, 2019; Dujovne, 2014, 2016; Dujovne y Sorá, 2010; Dujovne y García, 2011/12; Espósito, 2008; Sorá, 2002, 2011/12).

3. Las citas respetan la ortografía de los libros tal como fueron publicados en el siglo XIX. Se estimó pertinente mantenerla dado que se intenta darle forma a una historia de la lectura.

4. Más allá del nombre que la publicación se da así misma, por las características que presenta, es un almanaque. Estos como género editorial nacieron al mismo tiempo que la imprenta de Gutenberg y si bien su evolución está ligada a la del impreso en Occidente comenzaron a proliferar en el siglo XVII adquiriendo más tarde un amplio desarrollo. De acuerdo a la definición que brinda D. Buonocore para el almanaque rioplatense, este presentaba el registro o catálogo que comprendía todos los días del año, distribuidos por meses, con datos astronómicos y con otras muchas noticias relativas a los actos religiosos y civiles, principalmente de santos y festividades (Buonocore, 1948:95)

5. Esta es una cuestión que requiere mayores indagaciones, no solo porque no fue posible encontrar (hasta el momento) ningún ejemplar del Almanaque Moderno Sudamericano sino porque podría condensar un modelo de lector ideal, ya que Juan Schürer-Stolle aparece como el editor de ambas publicaciones. 
Imagen 1. Publicidad del Almanaque Moderno Sudamericano

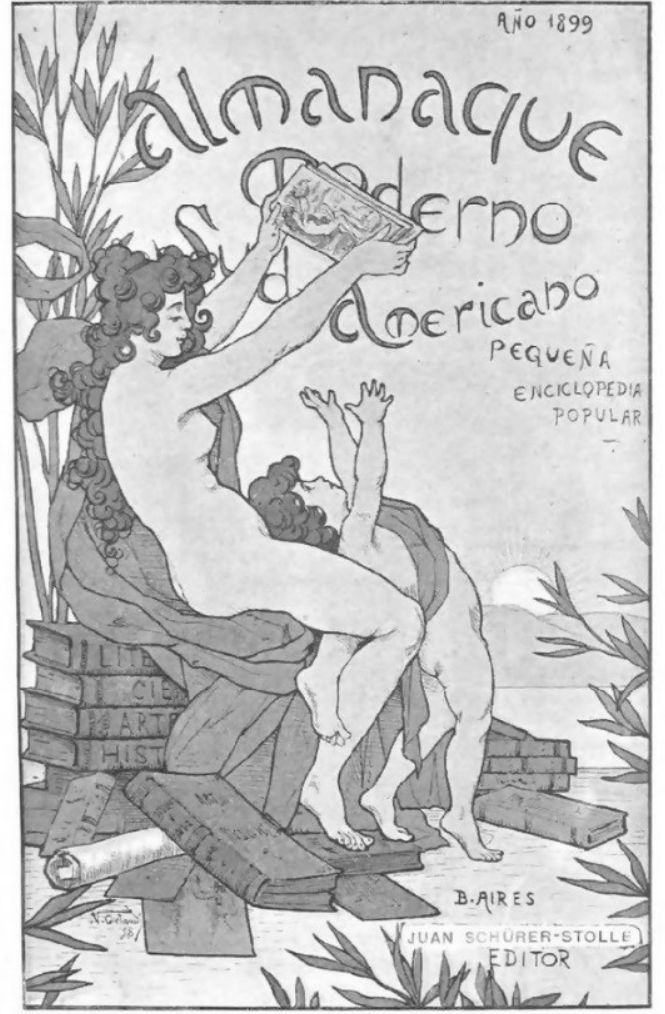

fotografía y el grabado para ilustrar la enorme cantidad de información que brindaban en sus páginas (Parada, 2000), y junto a otras publicaciones del momento, parecía mantener algunas características que lo habían definido a principios de siglo: era usado por una amplia población de lectores por su fácil lectura y manipulación, su consulta rápida y su precio accesible (Parada, 2007: 76), sumando a ellos otra práctica, la conservación. Como parece indicarlo El Verdadero Calendario Perpetuo (1858) arreglado por Pablo E. Coni, los almanaques no se desechan. En este caso, el editor afirma que al permitirle a los lectores encontrar todas las fiestas, los exime de la necesidad de comprar uno nuevo cada año, a lo que añade que basta con una mirada para conocer la utilidad de este calendario que da noticias de los siglos pasados y venideros (Verdadero Calendario Perpetuo, 1858:3-4). Esto evidencia que estas obras no solo tenían múltiples lectores sino también múltiples lecturas, y aunque estas no eran intensivas, se podía volver a él cada vez que se necesitaba algo, desde releer un cuento, una rima, una crónica de viajes hasta relatos históricos, recetas de cocina o algún dato que ayudara en la vida cotidiana, de modo que se lo conservaba y se lo utilizaba habitualmente (Mosqueda, 2013: 124)... al parecer había lectores, pero ¿cómo encontrarlos?

Podrían seguirse los consejos que Alberto Martínez escribe en Elmovimiento intelectual argentino (1887); este libro, que había sido puesto a disposición del público en el diario La Nación como artículo el 7 y 8 de enero de 1887 sostenía que,

para completar este estudio, ni el dato de la poblacion escolar, ni el del número de periódicos, ni el de las asociaciones científicas, literarias ó de bellas artes, son suficientes para medir por sí solos el progreso de la inteligencia argentina,

para ello hay que buscar otros aportes que permitan llevar adelante la investigación, 
interrogar los libros de nuestros libreros editores, para conocer cual es el monto de las ediciones que en el año se publican en Buenos Aires, cual es la aceptación que ellas tienen y el gusto que en el público propondera; y es indispensable tambien observar de cerca la marcha de nuestras cuatro bibliotecas públicas (Martínez, 1887: 12).

Algunos contemporáneos a Martínez, vinculados al circuito de la cultura letrada estaban preocupados por la escasez de títulos provistos por los intelectuales argentinos y lo limitado que era el consumo de esos materiales (Prieto, 1988: 15).

¿A cuánto asciende en Buenos Aires el número de obras de ciencia, de literatura, de artes, de historia, y escritas por autores nacionales ó extranjeros pero radicados en el país, que anualmente se ponen por las prensas argentinas en la circulacion de las ideas? ¿Existe ya en Buenos Aires una industria librera, que se alimenta exclusivamente de productos nacionales, como la hay en otros centros civilizados que tienen la misma ó ménos poblacion que esta ciudad? (Martínez, 1887: 13).

Si bien para contestar estas preguntas se cuenta con el Anuario Bibliográfico de la República Argentina, de Alberto Navarro Viola ${ }^{6} \mathrm{y}$, en la década de 1880 , se publicaron más de 100 títulos que conformaran el repertorio de la narrativa nacional, mientras se instalaban en el país algunas casas editoras de prestigio como Kraft, Peuser o Estrada (Laera, 2003).

$¿$ Quiere esto decir que hay ya entre nosotros un mercado abierto donde se cotizan las obras de nuestros primeros hombres de letras ó de ciencia; que la industria librera alimentada exclusivamente con productos nacionales existe ya aquí; que, en una palabra, el hombre que se siente con aptitud para descollar en la historia, en las letras ó en las ciencias, puede entregarse sin inquietudes por el dia de mañana, á sus trabajos, seguro de que sus esfuerzos serán debidamente recompensados? (Martínez, 1887: 15).

Alberto Martínez sostiene que, aunque se observan maravillosos progresos materiales que están cambiando radicalmente la faz del territorio argentino, todas esas cuestiones se responden negativamente ya que son pocos los que cumplen con esos grandes deberes que tiene el hombre consigo mismo y con sus semejantes: instruirse para instruirlos, cuestión que evidencia la Biblioteca Pública cuando muestra que en años la cantidad de lectores no ha variado y que sus estanterías tampoco se nutren de nuevos materiales (Martínez, 1887).

Ante esto, algunas cuestiones se imponen a la reflexión y al análisis. Si los lectores no quieren instruirse, ¿por qué llevar adelante el esfuerzo intelectual de escribir un libro?, ¿por qué afrontar el desafío de editar un libro cuando el mercado parece ser inexistente?, ¿dan cuenta del mundo del libro y la lectura los argumentos que presenta A. Martínez? Para esos hombres, las evidencias parecían ser contundentes e incuestionables, más aún si se veían a los lectores como pedantes, ignorantes, maliciosos y distraídos... nuevamente aparecen lectores, pero no son los imaginados y aunque esto lleva a formular muchas más preguntas una parece imponerse: ¿es posible darle forma a una historia de la lectura en Argentina para el siglo XIX?

\section{Se lee como no se lee o de un libro a incontables bibliotecas}

Hasta ahora esta historia encierra una paradoja: se lee como no se lee. Si los almanaques tenían múltiples lectores y múltiples lecturas, en una sociedad que estaba expandiendo la cultura letrada ¿por qué escribir sobre los límites del desarrollo de
6. El Anuario bibliográfico de la República Argentina, 9 tomos publicados entre 1879 y 1887 , se proponía reunir, reseñar e inventariar toda la producción editorial argentina: desde publicaciones periódicas, libros y folletos hasta las tesis de doctorado, año por año. Alberto Navarro Viola se propuso aportar esta obra como una herramienta cultural, política y científica. Esta revista puede consultarse en: http://www.catalogoweb.com.ar/biblioteca-digital/ revistas-digitalizadas.html 
7. Agradezco los comentarios y sugerencias del Dr. Alejandro E. Parada que me permitieron acercarme a la historia de esta biblioteca y a sus libros.

8. Más información sobre la historia de la Academia Argentina de Letras (AAL) y su biblioteca puede encontrarse en el sitio web de la institución http://www. letras.edu.ar/?q=node/131 y en los artículos, publicados en el

Boletín de la Academia Argentina de Letras (BAAL), de Cortés del Pino, Juan. 1966. "La Biblioteca de la Academia" en Boletín de

la Academia Argentina de Letras. Tomo 31. $\mathrm{N}^{\circ}{ }^{119}$. Buenos Aires, Enero / Marzo. p. 131-143 (http:// www.catalogoweb.com.ar/wwwisis/ index/Boletin1966-119_131-143. html); Barcia, Pedro. 2002.

"Brevísima historia de la Academia Argentina de Letras" en Boletín de la Academia Argentina de Letras. Tomo 67. N ${ }^{\circ}$ 263-264. Buenos Aires,

Enero / Junio. p. 9-3o Conferencia pronunciada en la Jornada de Clausura de Homenaje a don

Alonso Zamora Vicente, el día 15 de marzo de 2002 (http://www. catalogoweb.com.ar/wwwisis/ index/Boletin2002-263-264_9-30. html); Parada, Alejandro E. 2006a.

"La biblioteca de la Academia Argentina de Letras: la historia y la memoria de los libros en el ámbito académico". en Boletín de la Academia Argentina de Letras. Tomo

71. $\mathrm{N}^{\circ} 285-286$. Buenos Aires. Mayo

/ Agosto. p. 413-448 (http://www. catalogoweb.com.ar/wwwisis/index/Boletin2006-285-286_413-448. html). En 1933, se publica el primer número del Boletín de la Academia

Argentina de Letras (BAAL), y

destacan entre esas 96 páginas,

una sección llamada "Bibliografía del castellano en la Argentina", que respondía a la decisión de crear un registro de todo lo que se había escrito sobre ese tema en el país, el acta de fundación, su estatuto y su reglamento (Boletín de la Academia Argentina de Letras. 1933. Tomo 1. $\mathrm{N}^{\circ}$ 1. Buenos Aires. Imprenta y Casa Editora Coni.

Enero / Marzo. (http://www.

letras.edu.ar/wwwisis/indice/ Boletin\%201933\%20-\%201.html)

9. Allí también funcionarían la Academia Nacional de Bellas Artes, el Museo Nacional de Arte Decorativo y la Comisión Nacional de Cultura. Dicho proyecto fue aprobado por la Ley № 12.351, sancionada el 21 de enero de 1937. los libros de autores argentinos?, ¿por qué caracterizar tan negativamente a los lectores? y si esto no era así ¿dónde encontrar las huellas de esas formas materiales que vehiculizaron textos que contribuyeron a modelarlos?, ¿cómo hallar a los lectores y los usos que le dieron a los libros?

Para complejizar esta cuestión y siguiendo a R. Darnton, se debe recordar que la lectura no fue, a lo largo del tiempo y en todos los lugares, la misma. Se trata de una actividad que implica una relación particular entre el lector y el texto, y aunque esta ha cambiado según las transformaciones sociales y tecnológicas, la Historia de la Lectura no puede reducirse a una cronología de esos cambios, en consecuencia ¿cómo construir esa historia de unos lectores cambiantes de textos mudables? (Darnton, 1993: 206).

El universo de lo escrito es de lo más vasto y variado, y si bien algunos documentos excepcionales permiten reconstruir experiencias de lecturas casi ninguno revela el momento en el que el lector le atribuye significado a los textos (con el agravante de que esos documentos también son textos que requieren interpretación), así que es un camino complicado el que se necesita recorrer para saber cómo lo escrito afectó a los lectores o como se transmitieron las ideas al mirar las letras impresas en papel. Esto lleva a la necesidad de explorar más archivos para desarrollar enfoques históricamente adecuados de prácticas de lectura que superen una colactánea de anécdotas.

Llegados a este punto, un nuevo camino invita a continuar la travesía y este nos lleva a una Biblioteca. Recorrer sus libros, sus títulos y sus autores, permite confrontar esa historia y esas categorías con los ejemplares que desde la materialidad nutrieron a un país con diferentes lecturas, generando marcos de referencia comunes, transmitiendo la herencia intelectual desde la palabra impresa, permitiendo articular tipologías sociales a la vez que desarrollar las responsabilidades cívicas del lector y de las dirigencias políticas. Así se puede pasar a recorrer este territorio: la Biblioteca “Jorge Luis Borges" de la Academia Argentina de Letras?.

Esta institución fue creada por decreto el 13 de agosto de $1931^{8}$ por el Presidente provisional de la Nación, general José Félix Uriburu, y su Ministro de Justicia e Instrucción Pública, don Guillermo Rothe. Al no contar con un edificio propio comienza a funcionar en sala de la planta baja de la antigua Biblioteca Nacional. En 1936, Matías Sánchez Sorondo, presentó un proyecto para adquirir el Palacio Errázuriz para que la Academia pueda funcionar allí, y luego de su aprobación se trasladará a esta nueva sede a mediados de la década del $40^{\circ}$.

En cuanto a su Biblioteca, en 1936, disponía de tres cuerpos de anaqueles, pero será gracias a la donación de los libros de Juan José García Velloso, aproximadamente unos 3.000 volúmenes de literatura argentina e iberoamericana, con preeminencia de obras teatrales, que se constituirá el legado fundante de la biblioteca académica. A partir de 1947, comienza una etapa que le permitirá ir incrementando su colección para contar, en la actualidad, con unos 130.000 volúmenes y más de 3.500 títulos de publicaciones periódicas (ente las colecciones abiertas y cerradas). Esto se debió a que se recibieron otras donaciones valiosas como la de Miguel Lermon, constituida principalmente por primeras ediciones argentinas del siglo XIX (cerca de unos 12.000 libros), legados como los de Enrique García Velloso, Luciano Abeille, Manuel Gálvez, Alfredo de la Guardia, Jorge Max Rhode, José Oría, Rafael Alberto Arrieta, Patricio Gannon, Rodolfo Ragucci, Carlos Villafuerte, Celina Sabor de Cortazar, José Luis Trenti Rocamora y otros curiosos, como el de Abraham Rosenvasser, especializado en Egiptología y Culturas Orientales, entre otros. El acervo de la Biblioteca se completa con la correspondencia literaria 
de autores como Roberto F. Giusti (986 cartas), Manuel Gálvez (2.818) y Atilio Chiáppori (1.509) y el índice de la correspondencia de Victoria Ocampo (4.330).

En consonancia con ese imaginario compartido que inscribe los textos ineludibles del siglo XIX y los ordena en una serie de títulos y autores ${ }^{10}$, es posible encontrar en su catálogo El Matadero de Esteban Echeverría, Una excursión a los indios ranqueles de Lucio V. Mansilla, el Facundo de Domingo F. Sarmiento, la novela Los misterios del Plata de Juana Manso, Amalia de José Mármol o los recuerdos de unos estudiantes del Colegio Nacional Buenos Aires en las hojas de Juvenilia de Miguel Cané, incorporando, también, la literatura gauchesca con la primera edición de El gaucho Martín Fierro con enmiendas y correcciones de puño y letra de José Hernández o el Fausto de Estanislao del Campo, manuscritos de José Mármol como El peregrino en el mar, o La primera noche de cementerio, de Eduardo Wilde. Sumando los nuevos clásicos del siglo XX, con Don Segundo Sombra de Ricardo Güiraldes; El libro de la paloma, de Ricardo Molinari; Cuadernos de viviry pensar de Carlos Mastronardi; La conspiración de los fantasmas (comedia en tres actos), de Manuel Mujica Laínez y los originales de la mayoría de las novelas de Manuel Gálvez, entre otros (Parada, 2006a: 431).

Encontrar esos títulos materializa las listas, permitiendo que la comunidad disponga de esos textos que generan identidad lingüístico-literaria a la vez que, preserva ese patrimonio común que le permite a sus ciudadanos participar en macronarrativas que, al contener territorios multiculturales, sirven como mecanismo de integración inclusive para los sectores menos favorecidos y las minorías (Beltrán Almería, 1996). De este modo se va tejiendo un primer entramando, donde si bien la Biblioteca (en este caso, la pensada) en el siglo XIX imprime una orientación de lectura, este no deja de ser un territorio imaginario en la que se lee una de las versiones posibles ${ }^{11}$. Detrás de esa literatura reducida a un conjunto de títulos hay mucho más ya que, desde un libro es posible darle vida a incontables bibliotecas, ya que cada lector con sus selecciones le dará un nuevo orden a los libros.

Basta una mirada al catálogo, y de allí más particularmente a la sección de Libros raros y valiosos del siglo $X I X^{12}$, para encontrar otras claves de interpretación, ya que estas materialidades de la Historia del Libro y de la Lectura encierran un mensaje que puede ser descifrado para traer del pasado al presente los modos de leer, las imágenes que representan la lectura, las huellas de sus propietarios, palabras escritas en los márgenes, exlibris, firmas o dedicatorias y otras formas de apropiarse de los textos (Stoddard, 1985; Jackson, 2001; Parada, 2012).
10. Para estas cuestiones pueden consultarse: Eujanián, A. 1999 "La cultura: público, autores, editores", en Bonaudo, M. (dir.), Nueva Historia Argentina. Buenos Aires: Sudamericana. T. 4. p. 545-605 y Sora, G. 2011/12. “El libro y la edición en Argentina. Libros para todos y modelo hispanoamericano" en Políticas de la memoria № 10/11/12, Anuario de Investigación del CeDInCl. p. 125-143

11. Esto lleva a considerar el concepto de canon literario. Sin dudas, este tiene un antes y un después de la publicación de The Western Canon. The Books and School of the Ages de Harold Bloom (1994), y si bien su definición encuentra sus orígenes entre los griegos, tras un proceso de resignificaciones pasó de ser (específicamente en e campo literario) una lista de obras escogidas por la excelencia en el uso de la lengua, que se puede reconocer en la originalidad, el dominio del lenguaje metafórico, el poder cognitivo, la sabiduría y la exuberancia en la dicción. Si bien Bloom proponía la reconstrucción de un canon tradicional y riguroso, que reivindicara el valor estético de la literatura por sobre los aspectos políticos, ideológicos, económicos o sociales, constituyéndose en un sistema de referencia que no privilegia la heterogeneidad sino la uniformidad, se parte de considerar que el canon surge a partir de criterios de selección basados en el conjunto de funciones que esa lista puede realizar. Una de las definiciones más conocidas del concepto de canon literario, es la que propone Enric Sullà, quien entiende a este como una lista o elenco de obras consideradas valiosas y dignas por ello de ser estudiadas y comentadas, agregando que dicho elenco de obras y autores sirve de espejo cultural e ideológico de la identidad nacional (Sullà, 1998:11).

12. Merece destacarse que parte de esta colección se encuentra accesible por Internet. Gracias al proyecto de digitalización se cuenta con una biblioteca virtual con imágenes del texto completo de cada obra. Entre las obras abiertas a la consulta (además de que no todos son libros) hay más firmas que las incluidas en el canon literario argentino, contándose con publicaciones de autores populares o nombres buscados por especialistas como Eduarda Mansilla de García -hermana de Lucio- y de Josefina Sagasta de Pelliza, Antonio Argerich, Julián Martel o Manuel Podestá. Link de acceso al Catálogo: http://www.catalogoweb.com.ar/biblioteca-digital/librosdigitalizados-por-aal-wikimedia.html. También cuenta con un portal propio en la Biblioteca Virtual "Miguel de Cervantes”, que puede visitarse en http://www.cervantesvirtual.com/portales/academia_argentina_de_letras/. Así, se puede acceder a otros materiales, como poesía gauchesca y literatura nativista; autores argentinos del siglo XIX y XX, a la Colección Pedro de Angelis, recopilación de obras y documentos relativos a la historia de las provincias del Río de la Plata, y libros de viajes, esencialmente de aquellos recorridos hechos por extranjeros en nuestro país. Por otra parte, se ha inaugurado una sección de "Revistas digitalizadas", entre las que se encuentran los títulos siguientes: La Ondina del Plata, El Álbum del Hogar, Anuario Bibliográfico de la República Argentina (dirigido por Alberto Navarro Viola), La Novela Semanal, La Novela Porteña, y El Mercurio de América. (http://www.catalogoweb. com.ar/biblioteca-digital/revistas-digitalizadas.html) Próximamente se podrá consultar en línea el Catálogo del Fondo Antiguo de la Biblioteca (libros impresos entre 1506 y 1807) formado por 760 títulos (1.489 volúmenes) 
Tabla 1. Cantidades de libros editados durante el siglo XIX en el Catálogo de la Academia Argentina de Letras

13. Los libros presentes en la Biblioteca de la AAL se digitalizan siguiendo este criterio: libros del siglo XIX (la mayoría se los ubica entre 1870 y 1900), de autores argentinos y editados en Argentina. Hay algunas excepciones, por ejemplo si tienen pie de imprenta en Europa, Uruguay o

Chile, y se corresponden a autores argentinos que se encontraban exiliados en esos países. La

lista se actualiza constantemente de modo que estos son los datos al momento de su última consulta: 27 de abril de 2019 .

14. Estos datos están lejos de reflejar la actividad editorial o de circulación de impresos en el Río de la Plata para la segunda mitad del siglo XIX. Para complementar estas cuestiones desde un análisis mercado editorial puede verse el trabajo de Pastormerlo, Sergio. 2005. "El nacimiento de un mercado editorial en Buenos Aires, 1880-189o" en Orbis Tertius, 10(11). Recuperado de: http:// www.orbistertius.unlp.edu.ar y de Diego, José (dir.) 2006. Editores y políticas editoriales en Argentina (1880-2000). Buenos Aires/ México: Fondo de Cultura Económica.

15. Las donaciones de las bibliotecas particulares se caracterizan por la dispersión de sus volúmenes debido a las decisiones que toman

los herederos en relación a los

libros que desean conservar. En algunos casos, terminan en librerías de viejo o, como los casos que aquí se estudian, se donan a una institución comprometida con un proyecto de difusión y conservación. Si bien esto da cuenta de los límites que encuentra una historia de la lectura es un elemento

valioso para iniciar el estudio de estas cuestiones y en esa tarea nos encontramos en este momento.

\begin{tabular}{c|ccccccccc|c}
\hline Sin fecha & \multicolumn{8}{|c|}{1800 (por décadas) } & 1900 \\
\hline & 10 & 20 & 30 & 40 & 50 & 60 & 70 & 80 & 90 & \\
\cline { 2 - 13 } & 17 & 1 & 8 & 13 & 28 & 57 & 167 & 289 & 334 & 43 \\
\hline
\end{tabular}

Sobre un total de 958 libros $^{13}$, se evidencia que hay más títulos a partir de 1870 , y si bien las tres últimas décadas del siglo XIX concentran más del $80 \%$ de los títulos ${ }^{14}$ esto podría deberse a otras cuestiones como las vinculadas a los intereses de quienes adquieren esos libros, la disponibilidad al momento de formar cada biblioteca o los ejemplares que fueron seleccionados para la donación o la adquisición ${ }^{15}$. (Tabla 2 en Anexo)

Almanaques, libros de lectura o libros para aprender idiomas, antologías, novelas y poesías, semblanzas de personajes históricos o recuerdos personales, los títulos y temas se multiplican, autores consagrados y perfectos desconocidos. Estas cuestiones muestran un sector dinámico con talleres gráficos, imprentas y librerías que crecen al pasar los años. Así los libros, que no son necesariamente textos consagrados, sino que están allí porque eran lecturas para disfrutar, crean bibliotecas diversas, donde ya no hay listas inalterables, sino sociales e históricas que toman forma a partir de elementos, políticos, económicos, culturales o ideológicos, que transforman la biblioteca en mi biblioteca, y tal como es posible leer en el Indicador Argentino.

Una casa sin Biblioteca sea el palacio de un gran rico ó el cuarto de un obrero, es un jardín sin flores. Hoy en día los amigos de los libros son muchos, muchos más que antes. Afortunadamente los bibliófilos propiamente dichos son pocos y es mucho mejor así, porque no siempre los bibliófilos leen sus preciosos volúmenes. Se ocupan más de la rareza de la encuadernación, que del contenido del libro. Cualquiera puede hoy hacerse una pequeña biblioteca. La ciencia y el libro están al alcance de todos los ingenios y de todos los bolsillos y sólo quién no quiere ó no piensa no posee una pequeña biblioteca. (Almanaque Indicador Argentino, 1899: 328).

\section{Mi pequeña biblioteca: donde los lectores despliegan sus prácticas}

Mediante el empleo de un método cualitativo e indiciario como el que propone Carlo Ginzburg, (1994) se puede encontrar las palabras de los autores, buscar las huellas de los lectores y seguir la tarea de los editores. Ellos, son los primeros que ayudan a desentrañar algunos de los usos que se realizan del libro al asegurar tanto la publicación de los textos como que los autores se hagan conocidos y reconocidos, en una especie de creación, consagración y transferencia de capital simbólico (Bourdieu, 2009: 223) y así, por su intermedio, puede comenzarse a reconstruir una historia de la lectura. Esto es lo expresa el Almanaque Peuser para 1888 , donde

en sus páginas encontrará el lector bellísimos trabajos de literatos de renombre, á quienes nunca agradeceremos suficientemente la generosa cooperación que con óptimo fruto de su inspiración, de su talento y de su ingenio, nos han prestado" (Almanaque Peuser, 1888:3)

Esto les permitirá, años más tarde, ofrecer para conocer algo más de las novedades de su librería y casa editora catálogos completos e ilustrados que se remiten gratis a todos los puntos del país (Almanaque Peuser, 1894:28). O los motivos que explican 
$-315-$

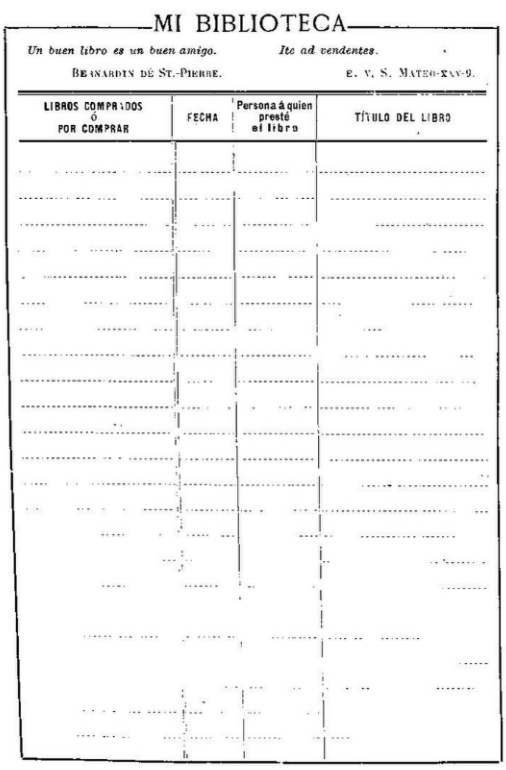

Imagen 2. Mi biblioteca en el Almanaque Indicador Argentino

la edición de la conferencia Artistas y poseuses de ese autor perfectamente conocido que había brillado en las letras americanas, Joaquín Lemoine, y que esperan, servirá de estímulo a otras ediciones posteriores (Lemoine, 1897: VI-VII).

Había un público deseoso de novedades, y tal como lo manifiesta Juan María Gutiérrez en la edición argentina del Lector Americano, esa colectánea, en prosa y verso, de fragmentos de historia, política y biografías, entre otros escritos de autores americanos, aunque perseguía los mismos objetivos que la primera edición que se había realizado en Chile, era diferente porque podría

estenderse en forma de série y convertirse en una verdadera «biblioteca de literatura Sud Americana» en la cual puedan cultivar bajo modelos y disciplinas pátrias, el uso de la palabra y el arte de espresarse por escrito los jóvenes argentinos. Segun fuere la estima que haga nuestro público de este ensayo, así será el desarrollo y la perfecion que daremos á nuestro libro el cual por ahora no es mas que una seleccion de lectura, útiles para toda clase de personas y en especial para la juventud que concurre á las escuelas y colegios. (Gutiérrez, 1874: 5-6)

Es interesante señalar que si bien las intenciones eran crear una biblioteca con lecturas que forman ciudadanos y libros que se usaran en la escuela pero que, a la vez, pudieran ser leídos en casa por toda la familia también está presente la separación de los contextos de producción y recepción, siendo estos últimos los que determinaran la decisión editorial de continuar, o no, con la colección. En consonancia con ello, Eduarda Mansilla de García pretende vivir en la memoria de los niños argentinos esperando remplazar con sus cuentos las narraciones olvidadas, y si bien funda en su fe en esa pléyade entusiasta y generosa que va a leerla, entiende y manifiesta que todo dependerá de la aceptación de su obra (Mansilla de García, 1880: VI). Ese también es el punto central en la Colección Peuser, que desplazando su interés hacia traducciones de la literatura inglesa, francesa, italiana y alemana, con tomitos de 98 páginas a 25 centavos cada uno y de aparición quincenal, espera contar con el apoyo del público para el éxito de la empresa (Mayer, 1886: 2). 
Hasta aquí las apelaciones a los lectores no permiten encontrar elementos que amplíen, confirmen o nieguen la caracterización hecha por el Almanaque Indicador Argentino, solo indican algo evidente: ellos son necesarios para la expansión de los proyectos editoriales. Necesarios pero no suficientes, porque si en Las aventuras de un criollo (circa 1880) se anoticia que para dejarle a sus amigos sus recuerdos en forma de poema se imprimieron 20.000 ejemplares, aunque poco se diga sobre los usos del libro dan cuenta de ese país repleto de lectores, donde circulaba una gran cantidad y diversidad de materiales de lectura, de modo que el público necesitaba ser conquistado.

Imprentas, talleres tipográficos, casas editoras y librerías comienzan a diversificar el panorama de la edición planteando a lo largo del tiempo diferentes estrategias, así los libreros cubren los costos de la edición, como D.A. Poroli con el Almanak patriótico de Buenos Aires para el año décimo de nuestra libertad (1819), o la posponen debido a la imposibilidad de cubrir los gastos como se indica en la Guía de la ciudad y Almanaque de comercio (1834) aunque da cuenta de los circuitos de comercialización, indicando que pueden comprarse los ejemplares directamente en la imprenta, en la casa del editor o en las librerías de Teófilo Duportail y de Pedro Lecerf.

Asimismo, otras prácticas se harán presentes en los libros como la que lleva adelante el editor de La Ondina del Plata, quien deseando corresponder la aceptación de su publicación le obsequiaba a sus numerosos suscriptores, una vez por año, una obra literaria y para comenzar a cumplir con su compromiso, edita el Álbum poético argentino (1877).

Nuevos datos surgen al revisar la Crónica de la biblioteca, que comparte con sus amados leyentes y escribientes Alejandro Magariños Cervantes (Cané, 1858: 236-294), dando cuenta, entre otras cuestiones, de los gastos de la imprenta, de las dificultades de la administración y de la distribución, las dudas del editor y las opiniones de la prensa. También aparecen las listas de suscriptores con las que

el curioso lector puede ejercitarse en la aritmética (a la vez que) los individuos, cuyos nombres falten ó estén equivocados, se sirvan avisar, si quieren, en el punto donde se hallan suscripto, y oportunamente se salvará la omisión ó el error en las listas sucesivas" (Cané, 1858: 273-277).

Esto ¿logra superar la anécdota? En principio parecería que no aunque permite caracterizar a otro lector: el de exhibición, donde importa reconocerse y ser reconocido al encontrar su nombre junto a destacadas personalidades del mundo de la cultura o la política, más allá de que, como afirme Héctor Varela en el Almanaque de Orion, "se lea o no se lea" (Varela, 1875: 1).

Por otra parte, no hay que dejar de considerar que esto no da cuenta de casos excepcionales solo permite conocer redes y prácticas de lectores anónimos que se pueden complementar con las constantes apelaciones que se hacen al lector como la de Estanislao del Campo con el poema que da inicio a Camila o la verdad triunfante al decir que "aquí teneis, amados carísimos lectores... Lanzad á mi Camila, tan solo una mirada" (Campo, 1856:3), o Las composiciones varias de Rodolfo Mendizábal quien “sin ninguna pretensión literaria había hecho la publicación, la deja para leerla y solo pide, para quien sea competente, el juzgarla". (Mendizábal, 1867:3). A ello podría sumarse que Roberto Payró reconoce ante sus lectores lo poco que vale la obra que vá á leerse, Antígona, escrita casi día por día para el folletín de un diario de la mañana, y que no hubiera podido publicarse si "sus amigos no hubiesen levantado una suscricion para lanzarla al público" (Payró, 1885: 3).

Autores y editores que buscan suscriptores para financiar una publicación y lecturas que apenas acarician los textos... Sin embargo, al volver al universo de la Biblioteca 


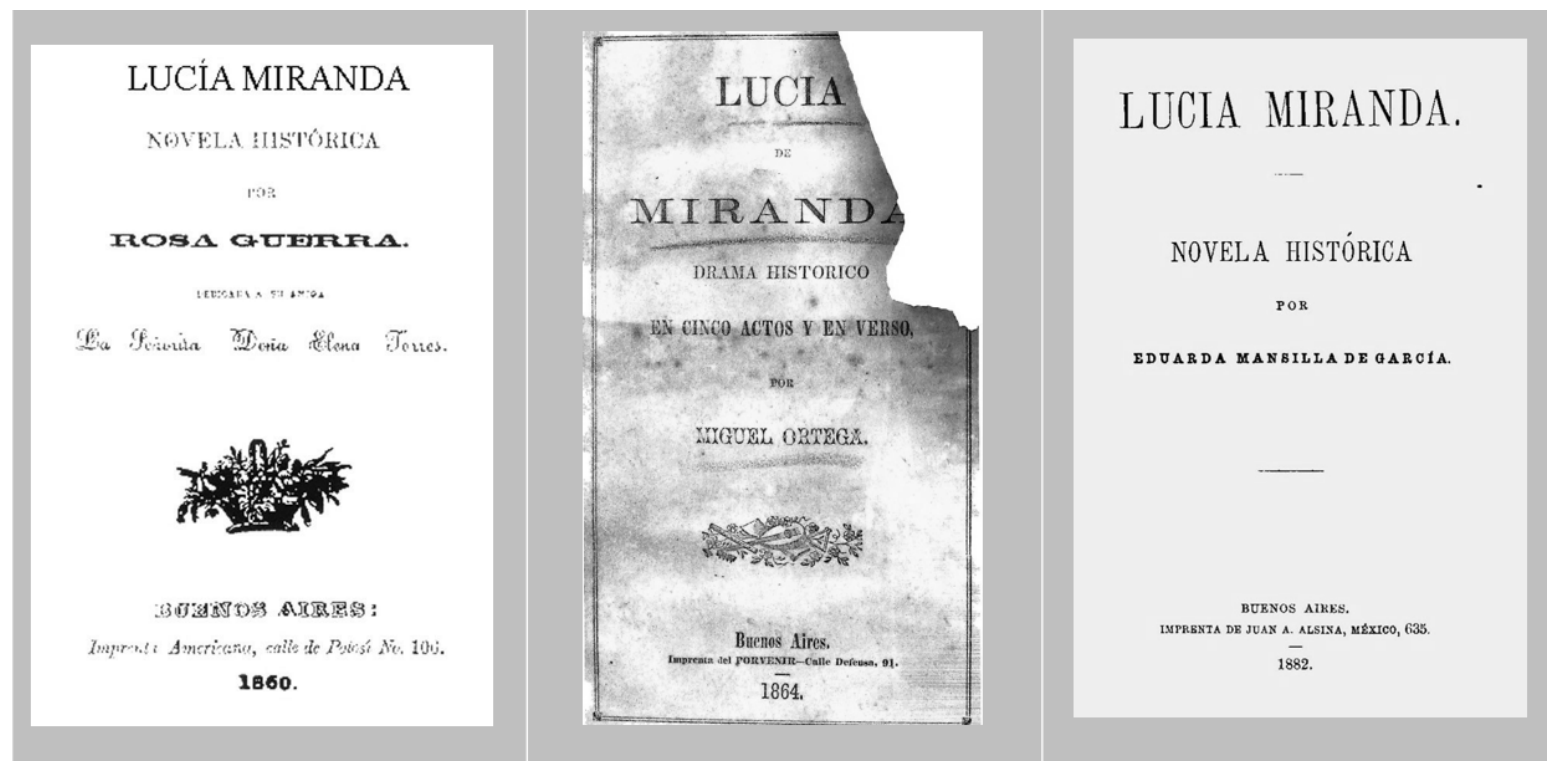

Imagen 3. Ediciones de Lucía Miranda presentes en la Biblioteca de la Academia Argentina de Letras

una cuestión interesante se presenta con unos de sus libros, las ediciones de Lucía Miranda. Esta historia se había hecho conocida por Argentina manuscrita o Anales del descubrimiento, población y conquista de las provincias del Río de la Plata de Ruy Díaz de Guzmán, que había sido escrito alrededor de 1612 pero recién editado por primera vez, en 1835, por Pedro de Angelis (Molina, 2005). Allí se encuentran tres ejemplares. Uno publicado, en 1860, por Rosa Guerra, una versión teatralizada del mismo drama de Miguel Ortega editado en 1864 y Lucía Miranda. Novela histórica de Eduarda Mansilla de García en 1882. Esta última era una nueva edición de su novela, "en plena posesión de su nombre verdadero" (Mansilla de García, 1882:7) ${ }^{16}$, y esto es interesante, no solo porque había aparecido por primera vez como folletín en el Diario La Tribuna y luego como libro bajo el seudónimo de Daniel, sino porque ese recorrido editorial será contemporáneo y similar a la publicación de la obra de Rosa Guerra.

Así, este entramado se va complejizando no porque se descubra algo nuevo al señalar que, luego de ser leído en folletín, un texto se podía materializar en un libro, sino porque se hacen presente otras formas de lectura. Estos textos son relecturas de la Historia de Díaz de Guzmán, que adquieren nuevas significaciones a mediados del siglo XIX. Además, esos imaginarios del pasado se reconstruyen tanto a través de la mirada de los hombres como la de las mujeres, (aunque en el caso de E. Mansilla actúan factores de ocultamiento y sinceramiento vinculados al uso del seudónimo) y, tal vez lo más interesante, es que las lecturas le dieron forma a ejercicios de escritura.

Sin embargo las dos novelas ofrecen más elementos para el análisis. La edición de 1882 de E. Mansilla comienza con una nota Allector donde señala que no ha cambiado ese texto, escrito veinte años atrás, ya que nunca acabaría de pulirlo y aún de borrarlo por lo cual le ha dejado ese sabor primero, entendiendo que tanto los defectos, como sus cualidades son inherentes a la juventud de su autor. Sin embargo, con una modificación en el título ya que pasa de llamarse Lucía, novela sacada de la historia Argentina (1860) a Lucía Miranda. Novela histórica (1882) y tras recuperar el verdadero nombre del autor, indica que lo que en ella había que corregir queda subsanado al introducir la palabra de su publicista Caleb Cushing (Mansilla de García, 1882: 5). La voz del
16. Estas cuestiones están desarrolladas en los trabajos de Lojo, María Rosa. 2003. Eduarda Mansilla: Entre la 'barbarie' yankee y la utopía de la mujer profesional. En Gramma. No.35: 14-25; Mansilla, E. Lucía Miranda (1860). 2007. Edición, introducción y notas de María Rosa Lojo. Madrid: Iberoamericana. 
17. Pablo ou la vie dans les pampas fue publicada como folletín en L'Artiste de París (1868) y luego aparecerá como libro, editado por E. Lachaud, Libraire- éditeur, 1869, en París. editor-lector se hace presente mediante la inclusión de una carta donde señala que ha disfrutado con gran placer la lectura Lucía, obra que

sufre más por negligencia en la edicion, que por defecto de composición. Déjemela Vd. dos ó tres días más, permitiéndome sugerirle la idea de hacer una edición en la forma y tan cuidada como su Pablo (Mansilla de García, 1882: 8).

Y tras comparar esa obra con la recién publicada ${ }^{17}$, el editor ofrece algunos indicios sobre los circuitos de circulación de los impresos y sus traducciones, envía una carta desde Washington, acaba de recibir el libro desde París mientras lee una traducción inglesa de una obra escrita en francés por una escritora argentina.

Este panorama se enriquecerá aún más con el libro de Rosa Guerra. La autora comienza advirtiendo que esta es una novelita escrita en los ocios de quince días, tiempo que mediaba de un certamen a otro siendo un trabajo que había quedado sepultado en el olvido porque dicho certamen literario, en el Ateneo del Plata, no sé había realizado (Guerra, 1860: 5). El género epistolar vuelve a cobrar centralidad ya que una carta de Miguel Cané oficiará de prólogo dando a conocer la opinión que tenía del texto:

...después de haberlo saboreado con toda mi atención, y si Vd. quiere aceptar mi elogio, puedo a Vd. repetir que es una de las producciones de nuestra literatura, que más gusto me haya causado. Encontrará Vd. algunos párrafos marcados por mí, que a mi juicio merecerían una reforma, no porque sean malos, sino porque no son tan bellos como los que figuran en el texto de la obra. Es una lectura a dos florones, como dicen los franceses: me parece que Vd. sería de mi opinión, y entonces creo completaría $\mathrm{Vd}$. su trabajo, digno de su talento y de la bella literatura argentina (Guerra, 1860: IV).

Aparece así otro lector, uno que tiene autoridad en el campo literario, que puede sugerir reformas en algunos párrafos y a la vez, al señalar que en ninguna creación, a excepción de Julieta y Romeo de Shakespeare, he encontrado más dulce poesía de amor, que entre los dos esposos de su novela (Guerra, 1860: V) la legitima en el ámbito de las letras.

Sin restar importancia a estas cuestiones, será en la dedicatoria a la Señorita Elena Torres donde aparecen otros usos del libro y las formas que adopta la lectura, que resultan muy significativos. Aunque se anuncia que esta edición se anticipa por pedido del público, a causa de estarse publicando otra novela con el mismo título y basada sobre el mismo argumento, esto parece ser una estrategia editorial sobre todo si se toma en consideración que en la advertencia se anunciaba que la novela había quedado en el olvido. De todos modos, otro acontecimiento de mayor importancia motiva la edición del libro, una promesa que nace de la relación de amistad entre Rosa Guerra y Elena Torres: He ahí mi regalo de boda que yo te tenía destinado para el día de tus nupcias, respondiendo aparentemente a lo señalado por E. Torres de que, la primera novela que yo lea ha de ser escrita por Vd. (Guerra, 1860: VII). Parece, sobre todo considerando lo dramático del contenido, un regalo poco apropiado para un evento de estas características, más aún si se toma en cuenta que la autora reconoce que al leer los episodios que acababa de escribir, se sentía bañada en lágrimas, cayendo estas sobre el papel y borrando los caracteres! (Guerra, 1860: XI).

De todos modos, lo interesante es que se reconocen múltiples formas de lectura. A esa lectura individual, R. Guerra le suma los recuerdos de lecturas compartidas: leyendo ambas este patético episodio de la Historia Americana (Guerra, 1860: VI), que volverán a transformarse tras la publicación del libro, de modo que puede ser que 
las mujeres no lean novelas pero si comparten lecturas que cimientan el papel que deberán jugar en la sociedad que se está construyendo ${ }^{18}$.

Por último, esas lecturas también presentan distintas dimensiones, hay un círculo cercano donde se comparten pero también son lecturas socialmente reconocidas, ya que R. Guerra afirma que después de más de tres siglos y medio, la lectura de tus desgracias en estas mismas comarcas donde fué consumado tu martirio, hacen derramar lágrimas á todos cuantos las leen (Guerra, 1860: VIII). Y esto lleva a rescatar otro de los motivos que habían llevado a la edición de esta obra, ya que señala

Dos mujeres tambien de estás mismas rejiones, sin tratarse, sin comunicarse sus ideas, herida en lo mas vivo su imajinacion por tus desgracias, toman tan tierno y doloroso argumento para basar cada una su novela, cuya lectura conmoverá los corazones menos sensibles (Guerra, 1860: VIII).

¿Dos mujeres?... ¿no había publicado con seudónimo E. Mansilla?... y ¿sin comunicar sus ideas?... ¿no habían aparecido como folletín estas obras?... Un mes media entre la aparición de estas dos novelas, la más extensa de E. Mansilla, que en más de trescientas proporcionará un contraste entre el trasfondo histórico europeo y este Nuevo Mundo y la Lucía Miranda de Rosa Guerra, que desarrolla la historia en cien páginas. Tiempo después se le sumará otro género, una obra de teatro escrita en verso por Miguel Ortega, que resaltando otros valores pasará a integrar las versiones que sobre el tema de la cautiva nutrirán la literatura nacional.

El mundo de la lectura comienza a develar alguno de sus misterios mientras invita a desentrañar otros.

\section{Conclusiones}

Con estas indagaciones se ha tratado de comenzar a descubrir algunas de las estrategias desplegadas y sentidos compartidos alrededor la cultura impresa en Argentina a partir del siglo XIX. Partiendo de ese marco que provee la historia cultural una historia de la edición, el libro y la lectura en la Argentina, puede comenzar a tomar forma, ya que este territorio con múltiples posibilidades de exploración, forma una historia cultural de la lectura, dentro de la cual se construye una historia de los actos de escritura, una historia de la producción y difusión de los testimonios impresos, una historia social de las gentes del libro: libreros, editores e impresores, una historia de las prácticas del taller y las costumbres obreras y una historia de los modos de leer, donde la disposición social de los textos le permite a los lectores vivir en otros mundos, reconstruidos y con nuevos significados.

Sin embargo, se siguen planteando desafíos, porque más allá que el Almanaque Indicador Argentino caracterice a los lectores como indiferentes, distraídos, ignorantes, malignos, pedantes y prejuiciosos parecen ser agentes activos de la edición. Sin embargo, esto no alcanza para señalar los usos del libro y las formas de lectura. Así que al ir en su búsqueda se ha iniciado una travesía que ha permitido llegar hasta la Biblioteca de la Academia Argentina de Letras. Un recorrido por su catálogo digital ha permitido corroborado que las listas no son inalterables y que estas son una construcción de hombres, construcciones en movimiento que crean múltiples órdenes de los libros y permiten organizar los libros en diferentes órdenes de lecturas.

Así, como en los almanaques donde podían incluirse los nuevos libros adquiridos o leídos, las bibliotecas podían ser enormes o pequeñas, pero los libros parecían, o podían, estar presentes en la casa de todos. Las lecturas se comentan en intercambios
18. De acuerdo a lo que sugiere E. Ortiz Gambetta (2012) esto hace referencia a la lectura de la Colección de obras impresas y manuscritas que tratan principalmente del Río de la Plata (1853), de Pedro de Ángelis que incluía la Argentina manuscrita de Díaz de Guzmán y que llegó a tener más de cuatrocientas suscripciones en el Río de la Plata. También Eduarda Mansilla señala en una carta a Vicente F. López que fueron las lecturas históricas las que dieron origen a su argumento novelístico. 
epistolares que se publican en los libros y estos se publican luego de que los textos hayan sido leídos en folletines. Esos textos integran los imaginarios compartidos, los autores y editores buscan suscriptores para financiar una publicación o solicitan su edición. Los lectores se reconocían en las listas de suscriptores, había lecturas en solitario y otras compartidas. Pero además las mujeres también podían formar parte de ese universo: leían y escribían. Esto permite comenzar a desentrañar las redes y prácticas de lectores anónimos.

Sin embargo, lo más importante es que comienza a materializarse la idea de que los libros formaron a los hombres y mujeres contenidos, formal o informalmente, en el concepto de ciudadanía y que intervenían en el espacio público debatiendo que país se quería construir y que lugar les era dado ocupar en él. Esto comienza a desentrañarse con las ediciones de Lucia Miranda, un texto del siglo XVII recuperado en múltiples lecturas en el siglo XIX, que se publica como folletín, como libro en distintos géneros $\mathrm{y}$ en varias ediciones.

Ojear el almanaque recreando esas prácticas, que hoy no nos son ajenas, ha permitido comenzar a encontrar nuevas claves de interpretación y elementos que parecen hacer viable escribir una historia de la lectura. Continuamos con la travesía... 


\section{Q Anexo}

\section{Tabla 2. Algunos libros e imprentas del siglo XIX presentes en el Catálogo de la Biblioteca de la Academia Argentina de Letras}

\begin{tabular}{|c|c|c|c|c|}
\hline Listado de títulos & Autor & Año & Editor / Imprenta & Ubicación en la ciudad \\
\hline $\begin{array}{l}\text { Almanak patriótico de Buenos Ayres } \\
\text { para el año décimo de nuestra libertad }\end{array}$ & Muñoz, Bartolomé & 1819 & $\begin{array}{l}\text { Imprenta de La } \\
\text { Independencia }\end{array}$ & $\begin{array}{l}\text { Cuadra y media del } \\
\text { cabildo para el oeste }\end{array}$ \\
\hline Argia & Varela, Juan Cruz & 1824 & $\begin{array}{l}\text { En la imprenta de } \\
\text { Hallet }\end{array}$ & \\
\hline Elvira o La novia del Plata & Echeverría, Esteban & 1832 & Imprenta Argentina & $\begin{array}{l}\text { De la Plaza para el } \\
\text { Colegio } \mathrm{N}^{\circ} 37\end{array}$ \\
\hline $\begin{array}{l}\text { Guía de la Ciudad y Almanaque de } \\
\text { comercio }\end{array}$ & Blondel, J. J. M. & 1834 & $\begin{array}{l}\text { Imprenta de La } \\
\text { Independencia }\end{array}$ & Chacabuco 19 \\
\hline La volkameria & Rivera Indarte, José & 1835 & $\begin{array}{l}\text { Imprenta de La } \\
\text { Libertad }\end{array}$ & Cangallo 58 \\
\hline Estatuto de la Sociedad Porteña & & 1837 & $\begin{array}{l}\text { Imprenta de La Gaceta } \\
\text { Mercantil }\end{array}$ & Cangallo 75 \\
\hline La rosa de marzo & Aguilar, Victoriano & 1843 & Imprenta del Estado & S/D \\
\hline Ecos del corazón & La Fuente, J. M. & 1844 & Imprenta de Arzac & S/D \\
\hline Mosaico literario. $T_{1}$ & $\begin{array}{l}\text { Wilde, Antonio F.; } \\
\text { Navarro Viola, }\end{array}$ & 1848 & Imprenta Republicana & $\begin{array}{l}\text { Calle del Restaurador } \\
\text { Rosas } 194\end{array}$ \\
\hline Camila o la verdad triunfante & Campo, Estanislao del & 1856 & De la Revista & S/D \\
\hline $\begin{array}{l}\text { Ensayo sobre la literatura de los } \\
\text { principales pueblos... }\end{array}$ & Labougle, Juan Eugenio & 1856 & $\begin{array}{l}\text { Imprenta y librería de } \\
\text { Bernheim }\end{array}$ & Defensa 73 \\
\hline Guía del preceptor & Sastre, Marcos & 1857 & $\begin{array}{l}\text { Librería de D. Pablo } \\
\text { Morta }\end{array}$ & $\begin{array}{l}\text { Frente al Colegio. Santa } \\
\text { Clara } 46\end{array}$ \\
\hline El verdadero calendario perpetuo & Coni, Pablo Emilio & 1858 & $\begin{array}{l}\text { Imprenta de La } \\
\text { Opinión }\end{array}$ & Corrientes \\
\hline Esther. Novela original & Cané, Miguel (p) & 1858 & Imprenta de Mayo & Representantes 128 \\
\hline Hojas de mirto & Loiseau, Ernesto de & 1859 & $\begin{array}{l}\text { Imprenta de la } \\
\text { Reforma }\end{array}$ & Perú 101 y 103 \\
\hline Lucia Miranda & Guerra, Rosa & 1860 & Imprenta Americana & Potosí 106 \\
\hline Composiciones varias de Espinillo & Espinosa, Pedro & 1863 & Imprenta de La Bolsa & San Martín 68 \\
\hline Lucia Miranda & Ortega, Miguel & 1864 & Imprenta del Provenir & Defensa 91 \\
\hline Atar-Gull & Mansilla, Lucio V. & 1864 & $\begin{array}{l}\text { Imprenta y litografía } \\
\text { a vapor de Berheim y } \\
\text { Boneo }\end{array}$ & Perú 117 \\
\hline Caridad & Paz, Carlos & 1865 & $\begin{array}{l}\text { Imprenta de La Nación } \\
\text { Argentina }\end{array}$ & San Martín 124 \\
\hline La flor de las tumbas & Estrada, Santiago & 1866 & Imprenta del Siglo & Victoria 151 \\
\hline Ensayos poéticos & $\begin{array}{l}\text { Cantilo, José M. (h) ; } \\
\text { Elías, José M. }\end{array}$ & 1869 & Imprenta del Plata & Potosí 198 \\
\hline
\end{tabular}




\begin{tabular}{|c|c|c|c|c|}
\hline Listado de títulos & Autor & Año & Editor / Imprenta & Ubicación en la ciudad \\
\hline Educación primaria y secundaria & Mitre, Bartolomé & 1870 & $\begin{array}{l}\text { Imprenta de la } \\
\text { sociedad Anónima de } \\
\text { La Nación }\end{array}$ & $S / D$ \\
\hline Cantos a Mayo & Rivas, Pedro & 1873 & Imprenta del Mercurio & Rosario 1873 \\
\hline $\begin{array}{l}\text { Cartas de Bilbao a Sarmiento } \\
\text { recopiladas por Unos amigos de la } \\
\text { verdad }\end{array}$ & & 1875 & Imprenta Rural & Belgrano $133-135$ \\
\hline Lo que puede el mate & $\begin{array}{l}\text { Torre y Torrens, } \\
\text { Francisco de la }\end{array}$ & 1877 & $\begin{array}{l}\text { Establecimiento } \\
\text { tipográfico de El } \\
\text { Orden }\end{array}$ & Perú 215 y 217 \\
\hline $\begin{array}{l}\text { Álbum de la caridad - Conferencia } \\
\text { literaria española }\end{array}$ & & 1877 & $\begin{array}{l}\text { Imprenta de "El correo } \\
\text { español" }\end{array}$ & Potosí 103 y 105 \\
\hline $\begin{array}{l}\text { Corona poética en honor del eminente } \\
\text { literato Juan Martínez Villergas }\end{array}$ & & 1878 & $\begin{array}{l}\text { Imprenta del Correo } \\
\text { Español }\end{array}$ & Potosí $103-105$ \\
\hline Buenos Aires en el año 2080 & Sioen, A. & 1879 & $\begin{array}{l}\text { Igon Hermanos, } \\
\text { Editores }\end{array}$ & Bolivar 60 \\
\hline Destellos de sabiduría & Bertoli, Ausonio & 1879 & Imprenta Del Pueblo & Defensa 78 \\
\hline Diccionario araucano-español & Febrés, Andrés & 1882 & $\begin{array}{l}\text { Imprenta de Juan } \\
\text { Alsina }\end{array}$ & $S / D$ \\
\hline $\begin{array}{l}\text { Conflicto y armonias de las razas en } \\
\text { América. Juicio crítico }\end{array}$ & Sarmiento, Domingo F. & 1883 & $\begin{array}{l}\text { Imp. Inglesa de Lowe, } \\
\text { Andersen y Ca }\end{array}$ & San Martín 117 \\
\hline Camila O’Gorman & Llanos, Julio & 1883 & $\begin{array}{l}\text { Imprenta de "La patria } \\
\text { Argentina" }\end{array}$ & Bolivar $92-112$ \\
\hline $\begin{array}{l}\text { El rudimentista. Metodo para la } \\
\text { enseñanza }\end{array}$ & $\begin{array}{l}\text { Nicolay de Caprile, } \\
\text { Emma }\end{array}$ & 1884 & $\begin{array}{l}\text { Librería Rivadavia de } \\
\text { Gustavo Mendesky } \\
\text { y Cia. }\end{array}$ & Rivadavia 95 \\
\hline Antígona & Payró, Roberto J. & 1885 & $\begin{array}{l}\text { Imprenta de Sud- } \\
\text { América }\end{array}$ & Bolivar 34 \\
\hline Auroras y ocasos & Godoy, Rodolfo & 1885 & $\begin{array}{l}\text { Litografía, imprenta } \\
\text { y encuadernación de } \\
\text { Stiller \& Laass }\end{array}$ & San Martín 160 \\
\hline La Babel argentina & Dávila, Francisco & 1886 & $\begin{array}{l}\text { Imprenta a Vapor del } \\
\text { Correo Español }\end{array}$ & Piedras 126 \\
\hline Carlo Lanza & Gutiérrez, Eduardo & 1886 & $\begin{array}{l}\text { Imprenta y } \\
\text { estereotipia de P. } \\
\text { Buffet y Cia. }\end{array}$ & Tucumán 23 \\
\hline Auroras y ocasos & Acosta, Alfredo & 1887 & $\begin{array}{l}\text { Imprenta de El } \\
\text { popular }\end{array}$ & Perú 143 \\
\hline Alberto Trejo & Mohr, Luis A. & 1888 & $\begin{array}{l}\text { Imprenta, } \\
\text { encuadernación } \\
\text { y librería de E. de } \\
\text { Mársico }\end{array}$ & Perú 297 \\
\hline Cuentos criollos: El capitán morillo & Soto, José Clemente & 1889 & $\begin{array}{l}\text { Establecimiento } \\
\text { tipográfico El Censor }\end{array}$ & Corrientes 829 \\
\hline Diccionario de barbarismos cotidianos & Seijas, Juan & 1890 & Kidd y Cia limitada & San Martín 351 \\
\hline Almanaque sudamericano 1893 & Prieto y Baldes, Casimiro & 1893 & El siglo ilustrado & $\begin{array}{l}\text { Buenos Aires: Cerrito } \\
170 \text { y 174; Montevido: } \\
\text { Soriano } 155 \text { y } 157\end{array}$ \\
\hline
\end{tabular}




\begin{tabular}{|l|l|c|l|l|}
\hline \multicolumn{1}{|c|}{ Listado de títulos } & \multicolumn{1}{|c|}{ Autor } & \multicolumn{1}{c|}{ Año } & \multicolumn{1}{c|}{ Editor / Imprenta } & \multicolumn{1}{|c|}{ Ubicación en la ciudad } \\
\hline Libro extraño I & Sicardi, Francisco A. & 1894 & Imprenta Europea & Moreno y Defensa \\
\hline Almanaque de las porteñas 1895 & Castilla Portugal, Manuel & 1895 & C. M. Joly y Cia. & Calle Victoria 719 a 727 \\
\hline Amor y lucha & Soria, Ezequiel & 1895 & $\begin{array}{l}\text { Casa editora de } \\
\text { Andrés Perez }\end{array}$ & Venezuela 1197 \\
\hline Byron & Díaz, Leopoldo & 1895 & $\begin{array}{l}\text { Editor: Jorge A. Kern } \\
\text { Librería e imprenta: } \\
\text { San Jorge }\end{array}$ & Santa Fe 2292 \\
\hline Los misterios del corazón & Barreda, Rafael & 1897 & $\begin{array}{l}\text { Casa editora de A. } \\
\text { Bietti }\end{array}$ & Tacuarí 239 \\
\hline $\begin{array}{l}\text { Colección de anécdotas. Tradiciones y } \\
\text { leyendas }\end{array}$ & F.M.Ch & 1898 & $\begin{array}{l}\text { Imp. Castex y } \\
\text { Hallisburton }\end{array}$ & Belgrano 650 \\
\hline Calandria & Leguizamón, Martiniano & 1898 & Ivaldi \& Checchi & Artes 635 \\
\hline Gesta & Ghiraldo, Alberto & 1899 & El sol & S/D \\
\hline
\end{tabular}




\section{Q Referencias Bibliográficas}

"Beltrán Almería, Luis. 1996. Canon y utopía. En Quimera. No. 146, 43-49.

"Bloom, Harold. 1994. The Western Canon: The Books and School of the Ages. New York: Harcourt Brace \& Company.

» Borges, Jorge L. 1988. Biblioteca Personal (Prólogos). Madrid: Alianza.

»Bourdieu, Pierre. 2009. Una revolución conservadora en la edición. En Bourdieu, Pierre. Intelectuales, política y poder. Buenos Aires: Eudeba. p. 223-267.

» Buonocore, Domingo. 1948. Elementos de bibliotecología. Santa Fe: Castellví.

"Chartier, Roger. 1993. Libros, lecturas y lectores en la Edad Moderna. Madrid: Alianza Universidad.

»Chartier, Roger. 1996a. El mundo como representación: Estudios sobre historia cultural. España: Gedisa.

»Chartier, Roger. 1996b. Escribir las prácticas: Foucault, de Certeau, Marin. Buenos Aires: Manantial.

"Chartier, Roger. 1999. Cultura escrita, literatura e historia. México: Fondo de Cultura Económica.

»Chartier, Roger. 2000a. El juego de las reglas: lecturas. México: Fondo de Cultura Económica.

»Chartier, Roger. 200ob. El orden de los libros: Lectores, autores, bibliotecas en Europa entre los siglos XIV y XVIII. Barcelona: Gedisa.

»Chartier, Roger. 2008. Escuchar a los muertos con los ojos. Buenos Aires: Katz.

»Chartier, Roger. 2016. La mano del autor y el espíritu del impresor. Siglos XVI-XVIII. Buenos Aires: Katz; Eudeba.

»Darnton, Robert. 1982. What is the History of Books? En Daedalus. Vol. 111, no. 3, $65-83$

»Darnton, Robert. 1987. La gran matanza de gatos y otros episodios en la historia de la cultura francesa. México: Fondo de Cultura Económica.

»Darnton, Robert. 1988. Historia intelectual y cultural. En Historias. Revista de la Dirección de Estudios Históricos del Instituto Nacional de Antropología e Historia. No. 19, 41-56.

»Darnton, Robert. 1990. The kiss of the Lamourette: Refelections in Cultural History. New York: Norton.

»Darnton, Robert. 1993. Historia de la lectura. En Burke, P., ed. Formas de hacer historia. Madrid: Alianza Editorial.

»Darnton, Robert. 2006. El negocio de la llustración. Historia editorial de la Encyclopédie, 1775 - 1800. México: Fondo de Cultura Económica.

"Darnton, Robert. 2014. Censores trabajando. De cómo los Estados dieron forma a la literatura. México: Fondo de Cultura Económica.

»De Diego, José. 2006. Editores y políticas editoriales en Argentina, 1880-2000. Buenos Aires: Fondo de Cultura Económica. 
»De Diego, José. 2007. Políticas editoriales y políticas de lectura. En Anales de la educación común. Tercer siglo, año 3, n 6, Educación y lenguajes. p. 38-44.

"De Diego, José. 2009. Cortázar y sus editores. En Orbis Tertius. Vol. 14, no. 15. <http://www.memoria.fahce.unlp.edu.ar/art_revistas/pr.4197/pr.4197.pdf> [Consulta: 20 abril 2019].

"De Diego, José. 2015. La otra cara de Jano. Una mirada crítica sobre el libro y la edición. Buenos Aires: Ampersand.

»De Diego, José. 2019. Los autores no escriben libros. Aportes a la historia de la edición. Buenos Aires: Ampersand.

»De Sagastizábal, Leandro. 1995. La edición de libros en la Argentina. Una empresa de cultura. Buenos Aires: Eudeba.

"De Sagastizábal, Leandro. 2002. Diseñar una nación: un estudio sobre la edición en la Argentina en el siglo XIX. Buenos Aires: Norma.

»Dujovne, Alejandro. 2014. Una historia del libro judío. La cultura judía argentina a través de sus editores, libreros, traductores, imprentas y bibliotecas. Buenos Aires: Siglo XXI.

"Dujovne, Alejandro. 2016. La máquina de traducir: EUDEBA y la modernización de las ciencias sociales y humanas, 1958-1966. En Papeles de Trabajo. Vol. 10, no. 18. 123- 144.

"Dujovne, Alejandro y Diego García. 2011/12. Introducción a la literatura mundial. En Políticas de la Memoria. No. 10-12, 31-37.

"Dujovne, Alejandro y Gustavo Sorá. 2010. Un hecho de política cultural: Argentina en la República Mundial de la Edición. En Argentina país invitado de honor Feria del Libro de Frankfurt 2010. Buenos Aires, Ministerio de Relaciones Exteriores, Comercio Internacional y Culto. p. 217-223.

"Espósito, Fabio. 2008. Seix Barral y el boom de la nueva narrativa hispanoamericana: Las mediaciones culturales de la edición española. En Orbis Tertius. Vol. 14, 15. <http://www.orbistertius.unlp.edu.ar/article/view/OTv14n15do3> [Consulta: 20 abril 2019].

》 Ginzburg, Carlo. 1994. Mitos, emblemas, indicios. Morfología e historia. Barcelona: Gedisa.

" Jackson, H. Joaquin. 2001. Marginalia: readers writing in books. New Haven: Yale University Press.

»Laera, Alejandra. 2003. El tiempo vacío de la ficción. Las novelas argentinas de Eduardo Gutiérrez y Eugenio Cambaceres. Buenos Aires: Fondo de Cultura Económica.

»Molina, Hebe. 2005. Femenino/Masculino en Lucía (1860) de Eduarda Mansilla. En Alba de América. Vol. 24, no. 45-46, 373-391.

" Mosqueda, Ana. 2013. Para una tipología de los Almanaques porteños en los inicios del siglo XX. En Parada, Alejandro E., dir. Cruces y perspectivas de la cultura escrita en la Argentina: Historia de la Edición, el Libro y la Lectura. Buenos Aires: Instituto de Investigaciones Bibliotecológicas, Facultad de Filosofía y Letras, Universidad de Buenos Aires. p. 113-146.

" Ortiz Gambetta, Eugenia. 2012. Poblar el desierto argentino. Modelos de civilización en la novela de la Organización Nacional. En Nuevo Mundo: Mundos Nuevos. Extraits de thèses. <http://journals.openedition.org/nuevomundo/64136 > [Consulta: 20 abril 2019]. 
"Parada, Alejandro E. 200o. Lecturas y lectores en el Buenos Aires del Centenario. La cultura impresa en la vida cotidiana. En Leiva, A., coord. Los días del Centenario de Mayo. San Isidro: Academia de Ciencias y Artes de San Isidro. Tomo I, p. 277-308.

"Parada, Alejandro E. 2003. La historia del libro, de las bibliotecas y de la lectura en la Argentina. En EDUCyT. Noticias de Educación, Universidad, Ciencia y Técnica. Año 6, no. 214. <http://www.fcen.uba.ar/prensa/educyt/2003/ed214b. htm\#NOTA11> [Consulta: 20 abril 2019].

»Parada, Alejandro E. 2006a. La biblioteca de la Academia Argentina de Letras: la historia y la memoria de los libros en el ámbito académico. En Boletín de la Academia Argentina de Letras. Tomo 71, no. 285-286, 413-448.

"Parada, Alejandro E. 2006b. La historia de la lectura como laberinto y desmesura. En Hojas de Guarda. No. 1, 89-100.

"Parada, Alejandro E. 2007. Cuando los lectores nos susurran. Libros, lecturas, bibliotecas, sociedad y prácticas editoriales en la Argentina. Buenos Aires: Instituto de Investigaciones Bibliotecológicas, Facultad de Filosofía y Letras, Universidad de Buenos Aires.

»Parada, Alejandro E. 2012. El dédalo y su ovillo. Ensayos sobre la palpitante cultura impresa en la Argentina. Buenos Aires: Instituto de Investigaciones Bibliotecológicas, Facultad de Filosofía y Letras, Universidad de Buenos Aires.

»Parada, Alejandro E., dir. 2013. Cruces y perspectivas de la cultura escrita en la Argentina. Buenos Aires: Instituto de Investigaciones Bibliotecológicas, Facultad de Filosofía y Letras, Universidad de Buenos Aires.

»Prieto, Adolfo. 1988. El discurso criollista en la formación de la Argentina moderna. Buenos Aires: Sudamericana.

"Saferstein, Ezequiel. 2013. Entre los estudios sobre el libro y la edición: El "giro material” en la historia intelectual y la sociología. En Información, cultura y sociedad. No. 29, 139-166. <http://revistascientificas.filo.uba.ar/index.php/ICS/ article/view/678> [Consulta: 20 abril 2019].

"Sorá, Gustavo. 2002. Frankfurt y otras aduanas culturales entre Argentina y Brasil. Una aproximación etnográfica al mundo editorial. En Cuadernos de Antropología Social. No. 15, 125-143.

"Sorá, Gustavo. 2011/12. El libro y la edición en Argentina. Libros para todos y modelo hispanoamericano. En Políticas de la memoria. Anuario de Investigación e Información del CeDInCl. No. 10/11/12, 125-143.

"Sorá, Gustavo. 2013. El mundo como feria. In(ter)dependencias editoriales en la Feria de Frankfurt. En Comunicación y Medios. Vol. 27, 101-127. Doi 10.5354/07191529.2013.24917

"Stoddard, Roger. 1985. Marks in books: illustrated and explained. Cambridge, Mass.: Houghton Library; Harvard University Press.

"Sullà, Enric. 1998. El debate sobre el canon literario. En Sullà, Enric, comp. El canon literario. Madrid: Arco Libros. p. 11-34 


\section{Fuentes}

》A.VAS.Y.LA [Aureliano Vasconcelos y Laborda]. (circa 1880). Las aventuras de un criollo. Buenos Aires.

" Álbum poético argentino. 1877. Buenos Aires: La Ondina del Plata.

» Almanak patriótico de Buenos-Ayres para el año décimo de nuestra libertad. 1819. Buenos Aires: Imprenta de la Independencia.

»Almanaque indicador Argentino. 1898. Buenos Aires: Casa Editora, Imprenta y Encuadernación Juan Schürer-Stolle.

"Almanaque Peuser para 1895. 1894. Buenos Aires: Jacobo Peuser Impresor.

"Almanaque Sud Americano 1898. Buenos Aires: Librería del siglo llustrado.

»Blondel, J. 1834. Guía de la ciudad y Almanaque de comercio de Buenos Aires para el año de 1834. Buenos Aires: Imprenta de la Independencia.

"Cané, Miguel. (p) 1858. Ester. Novela original. Buenos Aires: Tipográfica de Mayo.

"Campo, Estanislao del. 1856. Camila o la verdad triunfante. Buenos Aires: Imprenta de la Revista.

»El Verdadero Calendario Perpetuo ó sea colección de los 35 calendarios. 1858. Corrientes: La Imprenta de La Opinión.

» Guerra, Rosa. 186o. Lucía Miranda. Buenos Aires: Imprenta Americana.

"Gutiérrez, Juan. 1874. El lector Americano. Buenos Aires: Imprenta y Librería de Mayo.

"Lemoine, Joaquín. 1897. Artistas y poseuses. Buenos Aires: Compañía Sud-Americana de Billetes de Banco.

"Mansilla de García, Eduarda. 186o. Lucía, novela sacada de la historia Argentina. Buenos Aires: Imprenta de La Tribuna.

»Mansilla de García, Eduarda. 188o. Cuentos. Buenos Aires: Imprenta de la República.

» Mansilla de García, Eduarda. 1882. Lucía Miranda. Novela histórica. Buenos Aires: Imprenta de Juan A. Alsina

"Martínez, Alberto. 1887. El movimiento intelectual argentino. Población Escolar, prensa, asociaciones científicas, comercio de libros, y bibliotecas. Buenos Aires: Imprenta de La Nación.

"Mayer, Edelmiro. 1886. Flores y perlas. Buenos Aires: Casa Editora Peuser.

» Mendizábal, Rodolfo. 1867. Las composiciones varias. Buenos Aires: Imprenta Buenos Aires.

"Ortega, Manuel. 1864. Lucía Miranda. Drama Histórico. Buenos Aires: Imprenta del Porvenir.

》Payró, Roberto. 1885. Antígona. Buenos Aires: Imprenta de Sud América.

"Varela, Florencio. 1875. Almanaque de Orion. París: Imprenta Hispano-Americana de Rouge, Dunón y Fresné. 
